\title{
ВЛИЯНИЕ НОВОСИБИРСКОГО ВОДОХРАНИЛИЩА НА ФОРМИРОВАНИЕ ГИДРОЛОГО-ГИДРОХИМИЧЕСКОГО РЕЖИМА ВЕРХНЕЙ ОБИ НА ЗАРЕГУЛИРОВАННОМ УЧАСТКЕ
}

\author{
Савкин В. М., Двуреченская С. Я., Кондакова О. В. \\ IMPACT OF THE NOVOSIBIRSK RESERVOIR ON THE FORMATION \\ OF HYDROLOGICAL AND HYDROCHEMICAL REGIME OF THE UPPER \\ OB RIVER IN THE REGULATED AREA
}

\author{
Savkin V. M., Dvurechenskaya S. Ya., Kondakova O. V.
}

\begin{abstract}
Аннотация
Введение. Создание Новосибирского водохранилища определило гидролого-гидрохимический режим Верхней Оби на зарегулированном участке, обеспечило комплексное многоцелевое использование речного стока сложившимся водохозяйственным комплексом, защиту от паводков территории нижнего бьефа. Обсуждаются различные факторы, влияющие на современные гидрологические и гидрохимические характеристики водохранилища: изменение гидрологического режима реки при зарегулировании ее стока, выражающееся в замедлении течений, изменении морфометрических характеристик, снижении водообмена; процессы переработки (абразии) берегов, процессы подтопления и образования оврагов, заиление прибрежных заливов и засорение акватории плавающей древесиной, а также накопление загрязняющих веществ в связи с замедлением течений. Методы. Использованы суточные коэффициенты водообмена для конкретных дат, в которые проводился отбор проб воды. Для выявления и оценки силы связи между рядами сопоставляемых показателей применялся коэффициент ранговой корреляции Спирмена. Результаты. Исследовано влияние одной из основных гидрологических характеристик - внешнего водообмена - на формирование гидрохимического режима водохранилища. Выявлены различия этих связей для лет разной водности (экстремально маловодного 2012 г. и многоводного 2013 г.). Показано, что для многоводного года проявляются наиболее сильные статистически достоверные связи между коэффициентами водообмена и рядом химических показателей. Заключение. Результаты исследования могут быть использованы для разработки рекомендаций в целях принятия управленческих решений по рациональному использованию водных ресурсов Верхней Оби на участке Новосибирского водохранилища и для оценки его водно-экологического состояния.

Ключевые слова: водохранилище, регулирование стока, маловодные и многоводные периоды, коэффициент водообмена, гидрохимические характеристики.
\end{abstract}

\begin{abstract}
Introduction. The creation of the Novosibirsk reservoir determined the hydrological and hydrochemical regime in the regulated area of the Upper Ob River, provided a comprehensive multi-purpose use of the river flow by the existing water utilization system, ensured protection against floods in the downstream. The paper discusses various factors affecting the modern hydrological and hydrochemical characteristics of the Novosibirsk reservoir: changes in the hydrological regime of the river in the case of flow regulation, which result in slowing-down of flows, changes in the morphometry, a decrease in water exchange; processes of reservoir bank transformation (erosion); processes of flooding and ravine formation; sedimentation of coastal bays and water clogging by floating wood; accumulation of pollutants due to the slowing-down of flows. Methods. The authors used the daily water exchange coefficients for specific dates when water samples were taken. To identify and evaluate the relationship between the series of comparable parameters, they applied the Spearman rank correlation coefficient. Results. The authors studied the impact of one of the main hydrological characteristics external water exchange - on the formation of the hydrochemical regime of the reservoir. They revealed differences in these relationships for years of different water content (extremely low-water 2012 and high-water 2013). The most significant correlations between water exchange coefficients and a number of chemical characteristics were determined for the high-water year. Conclusion. The results of the study can be used to develop recommendations for decision-making on the rational use of the Upper $\mathrm{Ob}$ water resources in the Novosibirsk reservoir area and for the estimation of its water and ecological status.

Keywords: reservoir, flow regulation, low-water and high-water seasons, water exchange coefficient, hydrochemical characteristics.
\end{abstract}




\section{Введение}

Разработка проектов гидроэнергетического использования рек бассейна р. Оби с учетом интересов водного транспорта, сельского хозяйства и обводнения рыбопромысловых озер началась в 1930-х годах прошлого столетия. Климатические условия отдельных регионов Сибири обусловливают необходимость управления стоком рек для создания условий эффективного функционирования уже существующих и проектируемых водохозяйственных комплексов. Созданное на Верхней Оби в 1959 году Новосибирское водохранилище стало единственным в бассейне Оби из планируемых в середине 1950-х годов семи ГЭС с водохранилищами [4]. Оно определило гидролого-гидрохимический режим водных ресурсов на зарегулированном участке и обеспечило комплексное многоцелевое использование речного стока и защиту от паводков территории нижнего бьефа.

Полный объем Новосибирского водохранилища составляет 8,8 км $^{3}$, полезный объем - 4,4 км ${ }^{3}$ при среднегодовом стоке реки в створе ГЭС $52 \mathrm{kм}^{3}$ и максимальном - $73 \mathrm{kм}^{3}$. Это позволяет осуществлять лишь неглубокое сезонное регулирование стока, что определяет функционирование сформировавшихся водных экосистем, особенно в маловодные сезоны года. Создание водохранилищ приводит к существенным изменениям в экосистеме реки. На эти изменения влияют объем водохранилища, сложившийся гидрологический режим, интенсивность эксплуатации его водных и биологических ресурсов $[1,5]$.

Многоотраслевой водохозяйственный комплекс, существующий на основе Новосибирского водохранилища, включает питьевое, промышленное и сельскохозяйственное водоснабжение, энергетику, водный транспорт, рыбное хозяйство, рекреацию [18]. Обеспечение г. Новосибирска и ряда крупных населенных пунктов области питьевой водой нормативного качества в необходимом количестве - задача первостепенной важности в связи с общей прогрессирующей деградацией водных экосистем в результате антропогенного загрязнения водных объектов Сибири. В этой связи исследование роли Новосибирского водохранилища в формировании современного гидролого-гидрохимического режима р. Оби на зарегулированном участке - весьма важная и актуальная задача.
Цель данного исследования - анализ влияния различных факторов, связанных с существованием Новосибирского водохранилища, на гидролого-гидрохимический режим Верхней Оби на зарегулированном участке, включая выявление связей различных показателей качества воды с характеристиками внешнего водообмена водохранилища на примере экстремально маловодного 2012 года и следующего за ним многоводного 2013 года.

\section{Материалы и методы}

Для исследования качества воды Новосибирского водохранилища по гидрохимическим показателям отбор проб воды проводился на основных створах в верхней, средней и нижней частях водохранилища (рис. 1) батометром Молчанова в летнее время с борта теплохода, в зимнее время - со льда с глубины $0,6 h$, где $h$ - глубина водохранилища в точке отбора. В отдельных случаях пробы отбирались точечным методом с нескольких глубин (двух или трех) [15].

Отбор проб проводили, как правило, ежемесячно, в ряде случаев 2-3 раза в месяц. Химико-аналитические работы выполнялись в аккредитованном отделе по контролю качества природных и сточных вод ФГУ «ВерхнеОбьрегионводхоз» Федерального агентства водных ресурсов РФ по стандартным методикам анализа природных вод [2].

Коэффициенты внешнего водообмена Новосибирского водохранилища вычислены по формуле Л. И. Дубровина [8] как отношение объемов сбросов через гидроузел к объему водохранилища, соответствующему фактическим данным об уровне воды за рассматриваемые периоды времени.

Для выявления связей химических показателей качества воды и характеристик водообмена были рассчитаны суточные коэффициенты водообмена для конкретных дат, в которые проводился отбор проб воды. Статистическую обработку результатов проводили с использованием пакета программ «STATISTICA 6.0». Для выявления и оценки силы связи между рядами сопоставляемых показателей использовали коэффициент ранговой корреляции Спирмена.

Результаты и обсуждение

Последствия создания Новосибирского водохранилища

Гидротехническое строительство на реках приводит к возникновению ряда негативных 
последствий, таких как переработка берегов, подтопление прибрежных территорий, образование оврагов, заиление заливов, засорение акватории плавающей древесиной, накопление в связи с замедлением течений загрязняющих веществ. В настоящее время антропогенный вклад в формирование качества поверхностных вод сопоставим с природной составляющей, что представляет угрозу устойчивому водопользованию. Эта проблема весьма актуальна в связи с возрастающим техногенным воздействием на экосистему, часто превосходящим влияние процессов самоочищения и снижающим очищающую способность водоемов $[16,19]$.

Образование Новосибирского водохранилища привело к значительному изменению скоростного режима р. Оби на участке от г. Камень-на-Оби до плотины ГЭС. Общей закономерностью распределения скоростей течения по длине водохранилища является постепенное уменьшение их от зоны выклинивания подпора к плотине. В связи с малой регулирующей способностью водохранилища почти весь приток воды, поступающий в него, проходит транзитом, за исключением периода наполнения водохранилища. Стоковые течения (вызванные поступлением вод с притоками и сбросами в нижний бьеф) на Новосибирском водохранилище наблюдаются в основном в пределах затопленного русла, в пойменной части, у левобережья они незначительны $[10,11]$.

Для водохранилищ специфичен процесс ветрового волнения. Обширные открытые акватории способствуют формированию и развитию ветровых потоков, вызывающих интенсивное перемешивание водной массы и образование ветровых волн. Волны на Новосибирском водохранилище, вызванные продолжительными ветрами господствующей юго-западной четверти, могут достигать высоты 3,2 м [3].

Создание Новосибирского водохранилища обусловило изменение температурного режима по сравнению с естественным состоянием реки, что связано с изменением морфометрических характеристик, замедлением водообмена и метеорологическими условиями. Прогревание воды в водохранилище в весенний период происходит позже, чем в реке, в связи с более поздними сроками освобождения ото льда. Распределение температуры воды по глубине и акватории водохранилища неодинаково. Более быстрый прогрев и охлаждение воды наблюдаются в верхней части водохранилища, что обусловлено небольшими глубинами и турбулентным перемешиванием. В нижней части водохранилища (наибо-

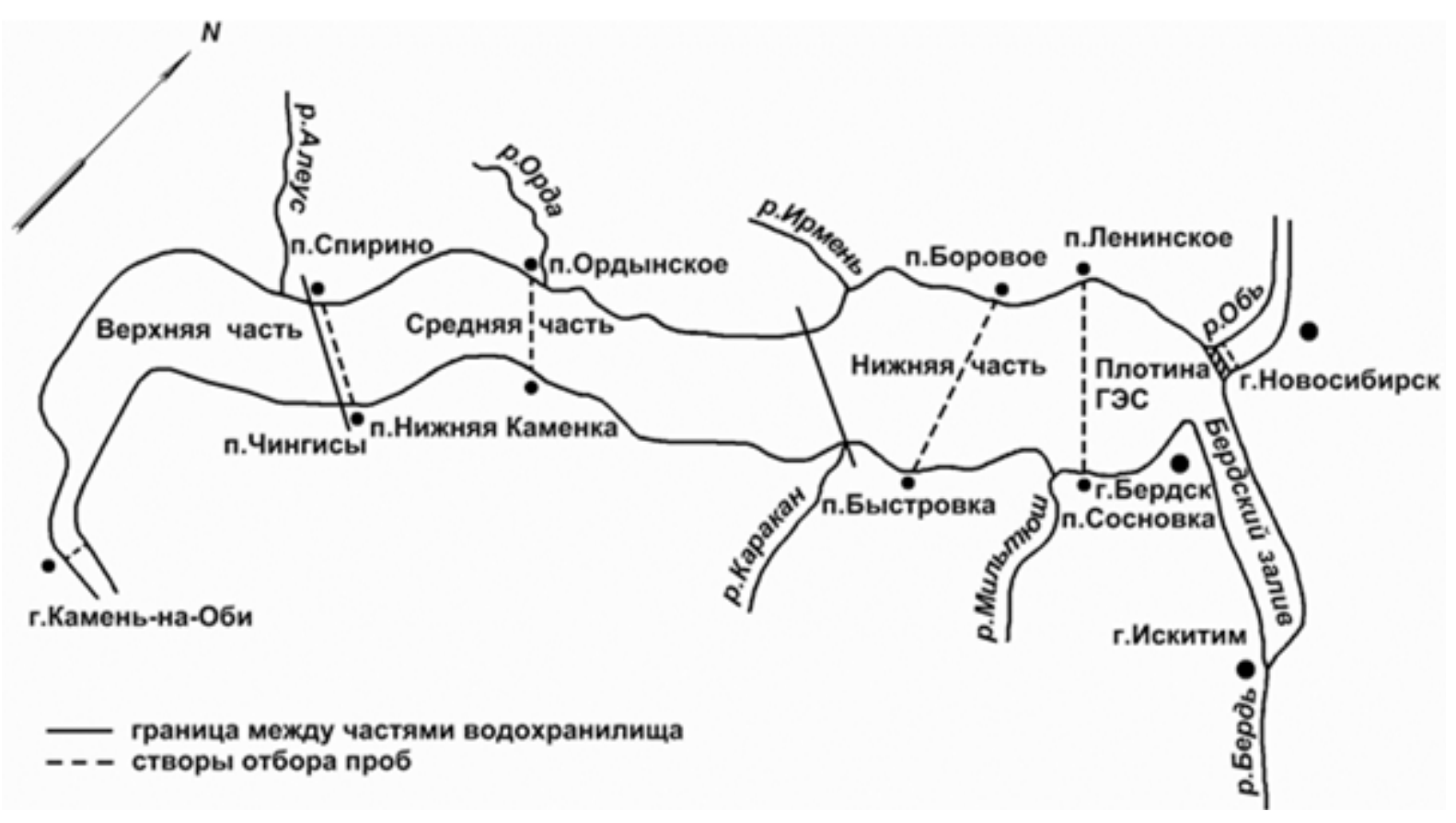

Рис. 1. Схема Новосибирского водохранилища 
лее глубоководной) значительна разница между значениями температуры поверхностного и придонного слоев. Существенно изменился температурный режим реки ниже водохранилища. Летом различие температуры воды в верхнем бьефе и в реке ниже плотины составляет $1-2{ }^{\circ} \mathrm{C}$. Зимой в нижнем бьефе в результате отепляющего влияния водохранилища образуется полынья; протяженность ее не превышает 30 км, в феврале-декабре она отсутствует.

Отмечается изменение твердого стока как на участке водохранилища, так и на значительном протяжении реки (600 км) ниже по течению. В связи с замедлением течений в водохранилище происходит осаждение взвешенных наносов. В нижнем бьефе на расстоянии 30 км ниже плотины годовой расход взвешенных наносов снизился в 3,5 раза; кроме того, произошло перераспределение твердого стока в течение года. Доля твердого стока в весенний период уменьшилась на 7,2\%, в летне-осенний и зимний периоды на 2,5 и 4,7 \% соответственно [10]. Максимальные расходы твердого стока наблюдаются на месяц позже по сравнению с естественным режимом.

Гидролого-гидродинамические условия Новосибирского водохранилища определяют процессы формирования и развития его берегов. В нижней и средней частях водохранилища определяющими факторами являются ветровое волнение и колебание уровня воды, в средней части оказывают влияние также стоковые течения. При стоянии уровней воды на отметках ниже нормального подпорного уровня (НПУ), соответствующих проектным уровням навигационной сработки, отмечается интенсивный размыв прибрежных отмелей и некоторое затухание переработки надводных склонов. При стоянии высоких уровней воды (близких к НПУ) происходит вспышка обрушений надводных склонов. В верхней и средней частях водохранилища на отдельных участках происходит образование оврагов, на пологих берегах в верхней части наблюдаются процессы подтопления. Процессы переработки берегов наиболее интенсивны в нижней части водохранилища (на расстоянии 60 км от плотины ГЭС) $[7,13]$.

Обрушение берегов - существенный источник поступления химических веществ в воды Но- восибирского водохранилища. Несмотря на то, что химический состав воды из района наиболее заметной абразии (п. Сосновка) и района с укрепленными берегами (п. Ленинское, рассматриваемом как фоновый, где берегозащитные сооружения были введены в эксплуатацию в 2006 г.) за 2006-2010 гг. практически одинаков, наблюдается некоторое повышение концентраций ряда химических показателей в районе п. Сосновка. Так, концентрации взвешенных веществ изменяются с 17,5 мг/дм ${ }^{3}$ (п. Ленинское) до 39,6 мг/дм³ (п. Сосновка); легкоокисляемых органических веществ

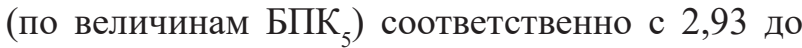
3,12 мг/дм², фосфатов - с 0,04 до 0,07 мг/дм², нефтепродуктов - с 0,015 до 0,019 мг/дм³ [3]. Таким образом, в перспективе для обеспечения устойчивого хозяйственно-питьевого водоснабжения за счет Новосибирского водохранилища особое внимание следует уделить природоохранным мероприятиям по строительству берегозащитных сооружений и организации водоохранных зон. Это в значительной степени снизит поступление загрязняющих веществ с собственного водосбора водохранилища.

В результате переработки берегов водохранилища происходит засорение акватории плавающей древесиной, топляками и коряжником, что приводит к ухудшению качества воды в связи с поступлением из древесины фенолов и других органических веществ. Плавающей лес наблюдается в средней и нижней частях водохранилища, скапливается у плотины, что осложняет работу ГЭС. В основном древесина поступает с водосборного бассейна р. Обь на территории Алтайского края и с берегов Новосибирского водохранилища. В связи с увеличением интенсивности переработки берегов в последнее время количество плавающей древесины существенно увеличилось.

Основные проблемы рационального использования водных ресурсов Верхней Оби связаны с недостаточностью зарегулирования стока, увеличением повторяемости маловодных лет и маловодных циклов, уменьшением водообмена (особенно весеннего сезона), сокращением времени стояния уровня воды в водохранилище на отметке НПУ, периодическим снижением уровня воды к началу весеннего наполнения водохранилища ниже уровня мертвого объема (УМО), 
«посадкой» уровня воды ниже плотины Новосибирской ГЭС, антропогенным загрязнением.

Новосибирское водохранилище осуществляет неглубокое сезонное регулирование стока. Это позволяет снижать расходы Верхней Оби в весенний период (апрель, май) на $29 \%$ от естественных [18], что оказывает положительное влияние на природные и хозяйственные условия в нижнем бьефе. Влияние водохранилища прослеживается ниже по течению реки на протяжении 600 км (г. Колпашево), где сток в период с декабря по март составляет 104-132\% естественного, в остальное время - 82-96\% [4].

Следует отметить, что по проекту Новосибирское водохранилище из-за малой полезной емкости не предназначено для предотвращения затоплений в нижнем бьефе. Полный объем водохранилища аккумулирует в среднем 17 \% годового стока, а полезный - $8,6 \%$. В многоводные годы полезный объем водохранилища аккумулирует 6-8 \% годового стока (в 1969 г. - 6,0 \%, в 2013 г. - 6,7\%, в 2017 и 2018 гг. - 7,7\%), в маловодные - 12-14 \% (в 1981 г. - 11,8 \%, в 2008 г. - 11,9\%, в 2012 г. - 14,2\%). Водохранилище позволяет срезать лишь небольшой пик паводковой волны. Максимальные расходы 0,1 и $0,01 \%$ обеспеченности практически не трансформируются. Поэтому высота уровня воды ниже плотины ГЭС определяется исключительно условиями наполнения водохранилища и безопасностью гидротехнических сооружений. При пропуске через сооружения ГЭС максимального расчетного расхода воды (порядка $21000 \mathrm{~m}^{3} / \mathrm{c}$ ) уровень воды на участке ниже плотины может быть достаточно высок. Поэтому строительство любых объектов в пойме реки следует запретить.

Анализ многолетних гидрологических характеристик Новосибирского водохранилища и его нижнего бьефа показывает, что, несмотря на незначительную зарегулированность стока в ствоpe ГЭС, имеются возможности использования водохранилища для срезки волн весеннего половодья и дождевых паводков на Верхней Оби, что позволяет избежать наводнений на участке реки от г. Новосибирска до устья р. Томи. Примером может служить снижение волн половодья и паводков в течение многоводного периода 20132018 гг.
Однако негативные последствия неспрогнозированных экстремальных дождевых паводков, осложненных наложением на формирование волны интенсивного весеннего снеготаяния, а также результаты многолетних наблюдений за трансформацией экосистемы Новосибирского водохранилища свидетельствуют о необходимости увеличения регулирования стока Верхней Оби на участке от слияния рек Бии и Катуни до г. Камень-на-Оби. Это тем более актуально в связи с увеличивающимися потребностями в водных ресурсах в условиях наблюдающегося значительного снижения притока к Новосибирскому водохранилищу в период зимней межени [14].

При обеспеченности притока к Новосибирскому водохранилищу в зимнюю межень более $60 \%$ возникает годовой дефицит водных ресурсов полезного объема водохранилища от 1,0 до $1,5 \mathrm{\kappa m}^{3}$ [18], что приводит к вынужденному понижению уровня воды ниже УМО. За период нормальной эксплуатации водохранилища 1960 2019 гг. (60 лет) сработка уровня воды ниже УМО осуществлялась в 40 годах. В экстремально маловодных 1981 и 1982 годах снижение уровня ниже УМО составило 1,28 и 1,9 м, соответственно, в 1998 г. - 1,53 м. В самом маловодном за весь период существования водохранилища 2012 г. уровень воды был сработан ниже УМО на 1,56 м. Низкий приток к водохранилищу в 2012 г. был обусловлен относительно малой водностью в осеннюю межень предыдущего года и низкими (ниже $50 \%$ от нормы) запасами снега в бассейне р. Катунь, а также отсутствием интенсивных осадков в летний и осенний периоды в бассейне Верхней Оби $[3,12]$.

Снижение уровня воды ниже УМО оказывает негативное воздействие как на экосистему водохранилища, так и на его водохозяйственное использование. При этом прекращают работу водозаборы питьевого назначения на водохранилище, оголовки которых, как правило, расположены на уровне УМО или несколько ниже. Наглядным примером может служить выход из строя водозабора г. Бердска в зимний период 2012 г. Только срочное инженерное решение этой проблемы, связанное с прокладкой временного водовода по льду от глубоководной части водохранилища до города, позволило избежать катастрофических последствий. Аналогичные условия скла- 
дывались на водозаборе п. Ордынское и других. Следует также учитывать различное качество бетона, уложенного в сооружения гидроузла. До отметки УМО гидротехнические сооружения, в том числе бетонная плотина, выполнены из морозоустойчивого бетона, ниже - из обычного. Осушение части сооружений из обычного бетона в условиях отрицательных температур может вызвать их разрушение и создать аварийную обстановку в целом на ГЭС.

Колебания уровня воды в Новосибирском водохранилище обусловлены как природными причинами - изменением притока воды к створу ГЭС, так и антропогенными - режимом попусков в нижний бьеф. Уровенный режим водохранилища - один из важнейших факторов, влияющих на его экологическое состояние, в частности на среду обитания и нереста рыб $[3,9,17]$. Колебания уровня воды водохранилища определяют неустойчивость его экологической системы в целом [17]. При понижении уровня воды в результате осенне-зимней сработки происходит осушение обширных площадей прибрежной мелководной зоны в верхней и средней частях водохранилища, особенно вдоль левобережья (при глубинах 2 м от НПУ), возможна массовая гибель рыбы в местах ее зимовки и нереста вследствие оседания льда и заморных явлений. Сработка уровня должна происходить равномерно и не ниже УМО. При вынужденном снижении ниже УМО средняя интенсивность сработки должна быть не выше 7-8 см/сут, что позволяет рыбам выйти из мелководной зоны водохранилища [9].

В период наполнения водохранилища большое значение для нереста рыб имеют сроки достижения отметки уровня в 112 м БС, при которой начинается затопление водной растительности на мелководных участках. Для аборигенных фитофильных рыб (щука, язь, плотва, окунь), наиболее требовательных к условиям нереста, благоприятные условия складываются в водохранилище только при затоплении мелководий в первой декаде мая. В течение сентября-октября (в период осенней сработки) во избежание нанесения существенного ущерба кормовой базе рыб в результате гибели донной фауны уровень воды не должен снижаться ниже отметки 112,5 м БС [9].

В маловодном 2012 году сложились экстремально неблагоприятные условия размножения рыб и развития сеголетков (и молоди в целом). При прогреве воды до нерестовых температур 7-8 ${ }^{\circ} \mathrm{C}$ в конце первой декады мая уровень воды в водохранилище был ниже НПУ на 3 м и составлял 110,50 м БС. Нерестовый субстрат для фитофильных рыб не был залит водой, в связи с чем икра откладывалась на грунт, крупный детрит и редкие древесные остатки. К положительным условиям нереста в 2012 г. можно отнести непрерывный и плавный подъем уровня воды, преобладание безветренной погоды и отсутствие резких перепадов температуры воды. Однако слабая обеспеченность рыб полноценными нерестилищами определила неэффективный нерест, особенно плотвы и окуня [3].

2013 год стал первым в серии многоводных лет (2013-2018 гг.). Характерной особенностью в период наполнения Новосибирского водохранилища и летне-осенней его эксплуатации в 2013 г. было регулирование уровня воды в водохранилище сбросами через водосливную плотину ГЭС, продолжавшимися практически 9 месяцев. Продолжительность наполнения водохранилища была больше среднемноголетней величины, что было связано с высокой водностью года и с необходимостью предотвращения негативных последствий в нижнем бьефе. В 2013 году отметка 112 м БС, при которой начинается затопление мелководий, была достигнута лишь к середине мая. В осенний период в 2012 и 2013 гг. сработка уровня воды ниже отметки, при которой начинается осушение основных мест нагула молоди рыб, не происходила.

Для многоводных 2013-2016 гг. общими чертами уровенного режима явились форсировка уровня выше отметки НПУ (в 2013 и 2015 гг.на 15 см, в 2014 г. - на 20 см, в 2016 г. — на 26 cм), а также повторное наполнение водохранилища до отметки НПУ в октябре-ноябре.

Динамика гидрологических характеристик Новосибирского водохранилища в 2012 и 2013 гг. показана на рис. 2 , характеристики основных фаз уровенного режима водохранилища приведены в таблице.

Исследование связи показателей качества воды с коэффициентами внешнего водообмена водохранилища

На формирование качества воды Новосибирского водохранилища в верхней его части основ- 

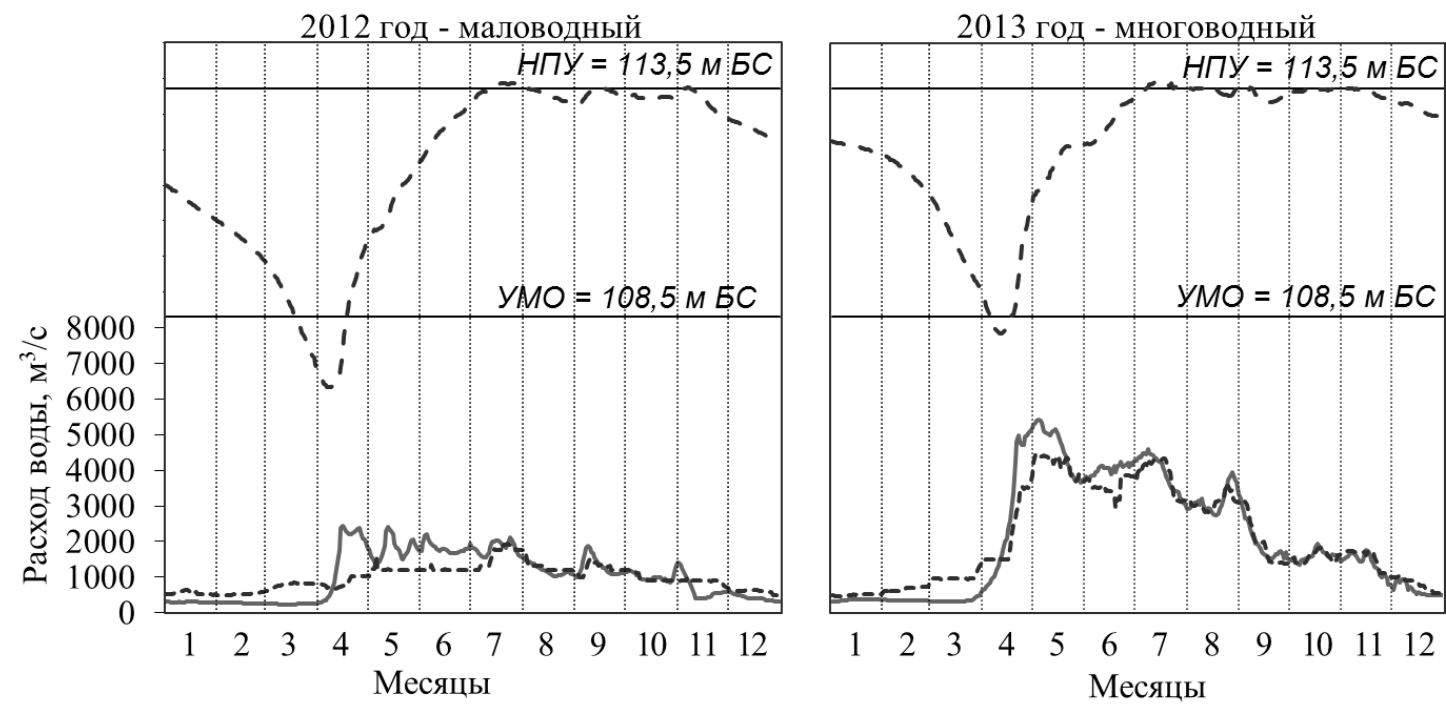

114,0

113,0 记

$112,0 \sum$

111,0 角

110,0

$109,0 \stackrel{0}{\stackrel{1}{*}}$

108,0

107,0

— Приток к створу ГЭС

----Сбросы ГЭС

- - Уровень воды

Рис. 2. Гидрологические характеристики Новосибирского водохранилища в маловодном 2012 г. и многоводном 2013 г.

\section{Характеристики основных фаз уровенного режима Новосибирского водохранилища}

\begin{tabular}{|c|c|c|c|c|c|c|}
\hline Год & 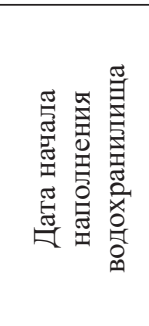 & 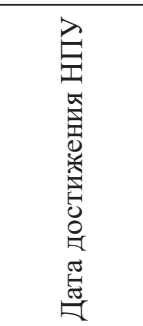 & 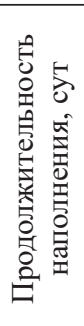 & 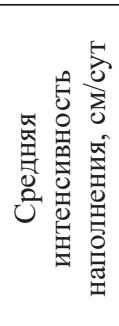 & 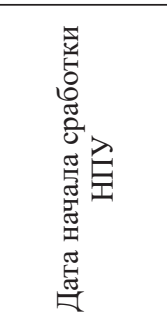 & 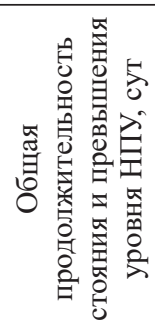 \\
\hline 2012 & 12 апреля & 12 июля & 50 & 8,2 & 9 ноября & 30 \\
\hline 2013 & 13 апреля & 7 июля & 86 & 6,2 & 8 ноября & 58 \\
\hline 2014 & 2 апреля & 23 июня & 83 & 4,7 & 28 августа & 63 \\
\hline 2015 & 12 апреля & 11 мая & 30 & 16,1 & 29 июля & 94 \\
\hline 2016 & 13 апреля & 3 июля & 82 & 6,1 & 25 августа & 45 \\
\hline 2017 & 11 апреля & 4 июля & 85 & 15,1 & 19 ноября & 32 \\
\hline 2018 & 6 апреля & 6 августа & 122 & 3,7 & 5 сентября & 21 \\
\hline Среднее за 1960-2018 гг. & 14 апреля & 12 июня & 60 & 9,91 & 25 сентября & 88 \\
\hline
\end{tabular}

ное влияние оказывает гидрохимический сток р. Обь, а на остальной акватории - внутриводоемные процессы [3]. В отдельные гидрологические сезоны года воды в водохранилище загрязняются нефтепродуктами, фенолами, а также нитритами и соединениями, содержащими ионы аммония [20]. Несомненный интерес представляет выявление связей химических показателей качества воды и гидрологических характеристик Новосибирского водохранилища. В настоящей работе исследовано влияние одной из основных гидрологических характеристик - коэффици- ентов внешнего водообмена $\left(k_{w}\right)$ на формирование гидрохимического режима водохранилища на примере маловодного 2012 г. и многоводного 2013 г. Эта характеристика выбрана для анализа, поскольку, как было показано [6], именно интенсивность водообмена в большей степени оказывает влияние на качество воды водохранилища.

При создании водохранилищ происходит замедление водообмена на зарегулированном участке по сравнению с естественными условиями. С внешним водообменом связан характер обмена растворенных веществ и взвешенных частиц. 
Под внешним водообменом понимается замена вод, находящихся в водоеме, новыми водами, поступающими извне [8]. При интенсивном водообмене в реках и проточных водоемах (в том числе водохранилищах) доминирует транзит вод и содержащихся в них взвесей и растворенных веществ через эти водные объекты; при замедленном водообмене, типичном для крупных озеровидных водоемов, преобладает аккумуляция вод и веществ в них. Чем интенсивнее водообмен, тем быстрее изменяются физико-химические свойства вод.

Поскольку получить полную картину при имеющихся средствах исследований не удается, внешний водообмен характеризуется условными показателями, рассчитываемыми по элементам водного баланса. Объем воды, выходящий из водоема путем стока (сброса), так или иначе заменяется новым, в то время как объем воды, поступивший в водоем с притоком, находится в нем длительное время (например, при наполнении водохранилища). Таким образом, сток лучше отражает регулируемые объемы и режим сброса воды, чем приток. Коэффициент внешнего водообмена является условным показателем, поскольку он рассчитывается в предположении, что вся водная масса водоема замещается новой [8].

Новосибирское водохранилище относится к водоемам с большим водообменом. Годовой коэффициент внешнего водообмена водохранилища в среднем составляет 6,67. В многоводные годы коэффициент водообмена равен 8,0-9,0 (в 1969 г. - 9,58, в 2010 г. - 8,32, 2013 г. - 8,58, в 2017 г. - 7,78, в 2018 г. — 7,56), в маловодные годы - 4,0-5,0 (в 1974 г. - 4,70, в 1981 г. 5,48, в 2008 г. - 5,10, в 2012 г. - 4,35). Наиболее интенсивно водообмен в Новосибирском водохранилище происходит в весенний период, максимальных показателей достигает в мае. В маловодном 2012 г. коэффициенты водообмена за весенний период и в целом за год были самыми низкими за весь период эксплуатации водохранилища. На рис. 3 приведены среднемесячные коэффициенты водообмена в маловодном 2012 г. и многоводном 2013 г. в сравнении со средними многолетними значениями.

Проведен корреляционный анализ между концентрациями основных гидрохимических показателей: главных ионов $\left(\mathrm{Ca}^{2+}, \mathrm{Mg}^{2+}, \mathrm{HCO}_{3}^{-}\right.$,
$\mathrm{Cl}^{-}, \mathrm{SO}_{4}^{2-}$ ), соединений, содержащих биогенные элементы (нитраты, нитриты, аммонийные соединения, фосфаты), значений легкоокисляемых органических соединений (по величинам БПК ${ }_{5}$ ), фенолов, нефтепродуктов и суточными коэффициентами водообмена в маловодном 2012 г. и многоводном 2013 г. В рассмотрение принимались значения концентраций химических ингредиентов в конкретные даты в течение исследуемых лет для всех створов.

Для многоводного 2013 г. выявлены сильные статистически достоверные связи между $k_{w}$ и $\mathrm{HCO}_{3}^{-}(-0,63), k_{w}$ и кислородом $(-0,51), k_{w}$ и $\mathrm{Ca}^{2+}$ $(-0,42), k_{w}$ и ионами $\mathrm{NH}_{4}^{+}(0,41)$. Для ряда хими-

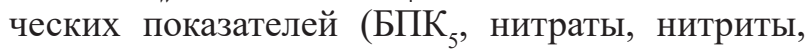
сульфаты) корреляционные связи с коэффициентами водообмена также статистически достоверны, но более слабые (менее 0,4). Для маловодного 2012 г. сильные статистически достоверные связи найдены только между $k_{w}$ и кислородом $(-0,52), k_{w}$ и ионами $\mathrm{Cl}^{-}(-0,46)$. Для фенолов, нефтепродуктов, аммонийных соединений, сульфатов, значений $\mathrm{pH}$ выявлены весьма слабые связи с коэффициентами водообмена; для остальных химических параметров достоверных связей выявлено не было. Таким образом, подтверждаются сделанные ранее выводы [3], что в многоводные годы качество воды в водохранилище в большей степени зависит от гидрологических характеристик, а в маловодные годы оно в основном определяется внутриводоемными процессами.

\section{Заключение}

Создание Новосибирского водохранилища определило гидролого-гидрохимический режим p. Оби на зарегулированном участке, обеспечило комплексное многоцелевое использование речного стока сложившимся водохозяйственным комплексом. Результатом зарегулирования стока явилось изменение гидрологического режима реки, выражающееся в замедлении течений, изменении морфометрических характеристик, снижении водообмена. Среди негативных последствий создания водохранилища - процессы переработки берегов, подтопления и образования оврагов, заиление прибрежных заливов и засорение акватории плавающей древесиной, а также накопление загрязняющих веществ в связи с замедлением течений. Однако Новосибирское водохранилище играет большую роль в обеспе- 


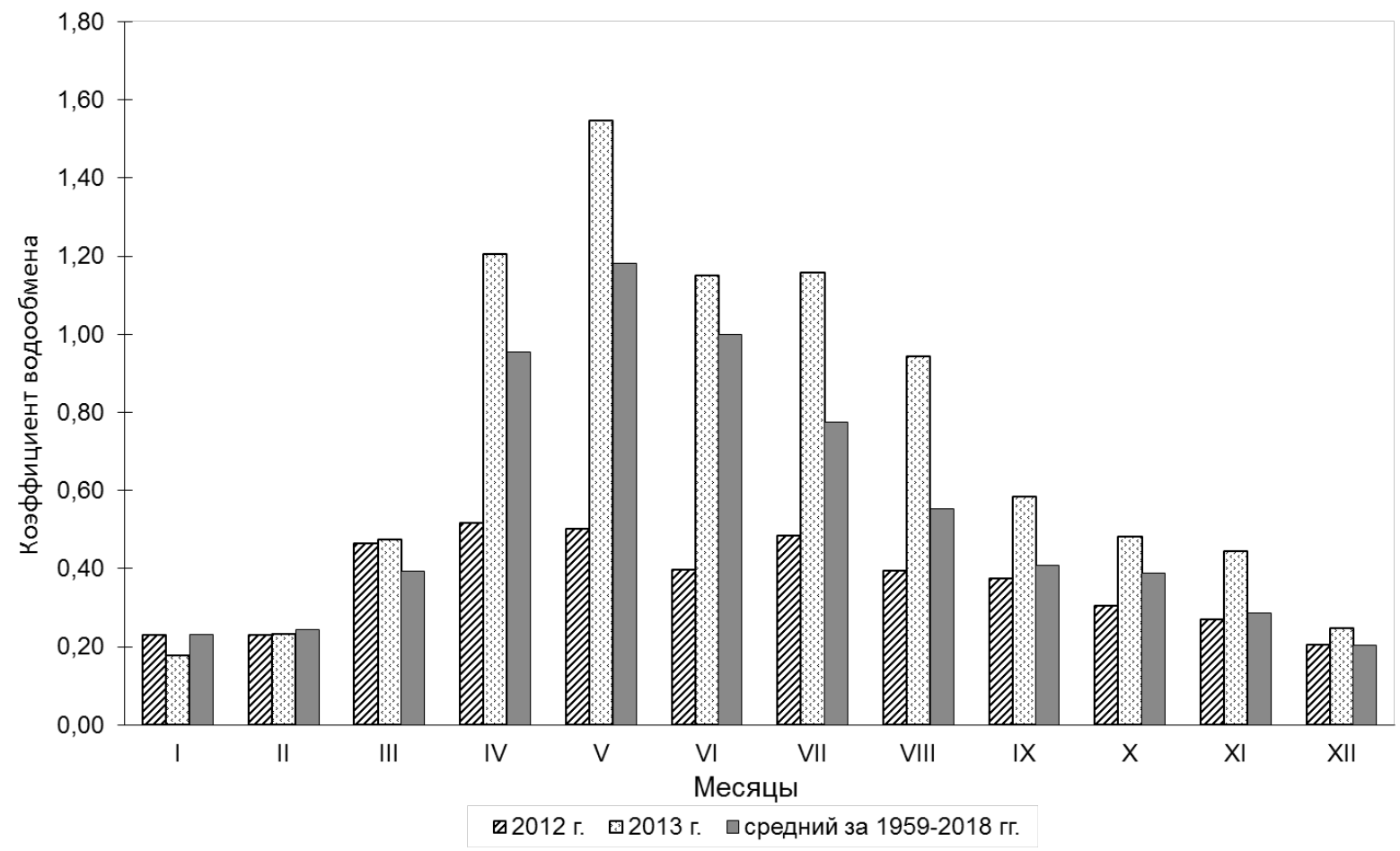

Рис. 3. Среднемесячные коэффициенты водообмена Новосибирского водохранилища в маловодном 2012 г., многоводном 2013 г. и средние многолетние значения

чении населения питьевой водой, создании природоохранных территорий, развитии рыбного хозяйства. Несмотря на малый полезный объем, Новосибирское водохранилище позволяет снижать объемы волн весеннего половодья и дождевых паводков Верхней Оби и тем самым предотвращать возможные наводнения на участке реки от г. Новосибирска до устья р.Томи.

Основные проблемы рационального использования водных ресурсов Верхней Оби связаны с недостаточностью зарегулирования стока; увеличением повторяемости маловодных лет и маловодных циклов; уменьшением водообмена (особенно весеннего сезона), сокращением продолжительности стояния уровня воды в Новосибирском водохранилище на отметке НПУ; периодическим снижением уровня воды к началу весеннего наполнения водохранилища ниже УМО; «посадкой» уровней воды ниже плотины Новосибирской ГЭС; антропогенным загрязнением. В течение всего времени существования водохранилища неоднократно возникали ситуации, когда в маловодные годы с недостаточным притоком в осенне-зимнюю межень уровень воды в водохранилище срабатывался ниже УМО. За последние десятилетия дефицит водных ресурсов водохранилища особенно явно проявился в 2008 и 2012 годах. Такие экстремальные ситуации возможны и в будущем, особенно при повторении серии маловодных лет, что может оказать негативное влияние на экосистему водоема.

Природные факторы, влияющие на гидролого-гидрохимический режим Новосибирского водохранилища, связаны с колебаниями стока p. Обь; антропогенные факторы обусловлены регулированием его водных ресурсов (режимом попусков в нижний бьеф), поступлением загрязняющих веществ в водные объекты от точечных и диффузных источников сточных вод.

Исследовано влияние внешнего водообмена на формирование гидрохимического режима водохранилища, выявлены различия этих связей для лет разной водности (для маловодного 2012 г. и многоводного 2013 г.). Впервые для Новосибирского водохранилища для анализа использовались суточные коэффициенты водообмена. Наиболее сильные статистически достоверные связи между коэффициентами водообмена и ря- 
дом химических показателей выявлены для многоводного года. Подтвержден вывод о том, что в многоводные годы качество воды в водохранилище в большей степени зависит от гидрологических характеристик, а в маловодные годы оно в основном, определяется внутриводоемными процессами.

Результаты данного исследования могут быть использованы для оценки водно-экологического состояния Новосибирского водохранилища и разработки рекомендаций в целях принятия управленческих решений по рациональному использованию водных ресурсов Верхней Оби на зарегулированном участке.

\section{Финансирование}

Работа выполнена в рамках государственного задания Института водных и экологических проблем СО РАН (Научная программа IX.134.1. «Исследование палео- и современных изменений состояния водоемов и водотоков Сибири, анализ природных и антропогенных изменений для стратегии охраны, использования и обеспечения безопасности водных ресурсов Сибири», проекты АAАA-A17-117041210240-7, АAАAA17-117041210241-4).

\section{Литература}

1. Авакян, А. Б., Салтанкин, В. П. и Шарапов, В. А. (1987). Водохранилища. М.: Мысль, 323 с.

2. Ассоциация «Moldova Apa-Canal» (2016). Перечень методик, внесенных в государственный реестр методик количественного химического анализа. Часть I. Количественный химический анализ вод. [online] Доступно по ссылке: http://www.amac.md/Biblioteca/ data/28/14/06/01/01.2.pdf [Дата обращения: 17.02.2020].

3. Васильев, О.Ф. (ред.) (2014). Многолетняя динамика водно-экологического режима Новосибирского водохранилища. Новосибирск: Изд-во СО РАН, 393 с.

4. Васильев, О. Ф., Бураков, Д. А., Вострякова, Н. В. и Савкин, В. М. (1990). Перспективы регулирования стока в Обь-Иртышском бассейне в связи с мелиоративным освоением территории. Гидрологическое обоснование водохозяйственных мероприятий. В: Труды V Всесоюзного гидрологического съезда, 20-24 октября 1986 г. Л.: Гидрометеоиздат, сс. 159-164.

5. Воропаев, Г. В. и Авакян, А. В. (ред.) (1986). Водохранилища и их воздействие на окружающую среду. М.: Наука, 367 c.

6. Двуреченская, С. Я., Ермолаева, Н. И. и Савкин, В. М. (2010). Комплексный мониторинг и экологические проблемы Новосибирского водохранилища. В: Материалы Всероссийской научно-практической конференции «Научные основы экологического мониторинга водохранилищ», 26-29 октября 2010 г. Хабаровск: ИВЭП ДВО РАН, сс. 53-56.

7. Жиндарев, Л. А. (ред.) (2009). Управление состоянием берегов водохранилищ. Новосибирск: СО РАН, 239 с.

8. Матарзин, Ю. М. (2003). Гидрология водохранилищ: учебник для вузов. Пермь: Издательство ПГУ, 295 с.

9. Попов, П. А. и Визер, А. М. (2011). Влияние уровенного режима Новосибирского водохранилища на репродуктивный потенциал рыб. Мир науки, культуры, образования, № 1 (26), сс. 353-356.

10. Савкин, В. М. (2000). Эколого-географические изменения в бассейнах рек Западной Сибири (при крупномасштабных водохозяйственных мероприятиях). Новосибирск: Наука. Сибирская издательская фирма РАН, $152 \mathrm{c}$.

11. Савкин, В. М. (2006). Современный гидрологический режим Новосибирского водохранилища в сравнении с многолетним. Гидрология и гидроэкология Западного Урала. Пермь: Перм. ун-т, сс. 5-12.

12. Савкин, В. М. (2015). Влияние Новосибирского водохранилища на трансформацию половодий и паводков экстремальной водности. В: Международная научно-практическая конференция «Современные проблемы водохранилищ и их водосборов». Т. 1. Гидрои геодинамические процессы управление водными ресурсами. Пермь: ПГНИУ, сс. 128-132.

13. Савкин, В. М. и Двуреченская, С. Я. (2017). Трансформация стока Верхней Оби под воздействием антропогенных факторов. В: Труды. VI Международной научно-практической конференции «Современные проблемы водохранилищ и их водосборов», Т. 1: Гидрои геодинамические процессы. Управление водными ресурсами. Пермь: ПГНИУ, сс. 227-231.

14. Савкин, В. М. и Двуреченская, С. Я. (2017). Формирование и использование водных ресурсов Верхней Оби (Новосибирское водохранилище) в природнотехногенных условиях. В: Труды III Всероссийской научной конференции с международным участием «Водные и экологические проблемы Сибири и Центральной Азии», Т. 3. Барнаул: Институт водных и экологических проблем CO РAH, cc. 266-277.

15. Электронный фонд правовой и нормативнотехнической документации (2011). Р 52.24.309-2011. Организация и проведение режимных наблюдений за загрязнением поверхностных вод суши на сети Росгидромета. [online] Доступно по ссылке: http://docs.cntd. $\mathrm{ru} /$ document/1200049047 [Дата обращения: 17.02.2020].

16. Calijuri, M. L., Castro, J. d. S., Costa, L. S., Assemany, P. P. and Alves, J. E. M. (2015). Impact of land use/ land cover changes on water quality and hydrological behavior of an agricultural subwatershed, Environmental Earth Sciences, Vol. 74, Issue 6, pp. 5373-5382. DOI: 0.1007/s12665-0154550-0.

17. Interesova, E. A., Yadrenkina, E. N. and Savkin, V. M. (2009). Spatial organization of the spawning grounds of cyprinidae and the regulated flow of the Upper Ob. Journal of Ichthyology, Vol. 49, Issue 1, pp. 73-79.

18. Savkin, V. M. and Dvurechenskaya, S. Ya. (2014). Resources-related and water-environmental problems of the 
integrated use of the Novosibirsk Reservoir. Water Resources, Vol. 41, Issue 4, pp. 446-453.

19. Setegn, S. G. (2015). Water resources management for sustainable environmental public health. In: Setegn, S. G., Donoso, M. C. (eds.) Sustainability of integrated water resources management: water governance, climate and ecohydrology. Cham: Springer, pp. 275-287. DOI: 10.1007/978-3-319-121949_15.

20. Vasil'ev, O. F., Savkin, V. M., Dvurechenskaya, S. Ya. and Popov, P. A. (1997). Water-management and environmental problems of the Novosibirskoe Reservoir. Water Resources, Vol. 24, No. 5, pp. 538-545.

\section{References}

1. Avakyan, A. B., Saltankin, V. P. and Sharapov, V. A. (1987). Water reservoirs. Moscow: Mysl, 323 p.

2. Moldova Apa-Canal Association (2016). List of methods introduced in the State Register of Quantitative Chemical Analysis Techniques. Part I. Quantitative chemical analysis of waters. [online] Available at: http://www.amac.md/Biblioteca/ data/28/14/06/01/01.2.pdf [Date accessed 17.02.2020].

3. Vasilyev, O. F. (ed.) (2014). Long-term dynamics of the water and environmental regime at the Novosibirsk reservoir. Novosibirsk: Publishing House of the Siberian Branch of the Russian Academy of Sciences, $393 \mathrm{p}$.

4. Vasilyev, O. F., Burakov, D. A., Vostryakova, N. V. and Savkin, V. M. (1990). Prospects for flow regulation in the ObIrtysh basin with regard to land reclamation. Hydrological justification of water management activities. In: Proceedings of the $5^{\text {th }}$ All-Union Hydrological Congress. Leningrad: Gidrometeoizdat, pp. 159-164.

5. Voropaev, G. V. and Avakyan, A. B. (eds.) (1986). Reservoirs and their environmental impact. Moscow: Nauka, $367 \mathrm{p}$.

6. Dvurechenskaya, S. Ya., Yermolaeva, N. I. and Savkin, V. M. (2010). Integrated monitoring and environmental issues of the Novosibirsk reservoir. In: Proceedings of the All-Russian Scientific and Practical Conference "Scientific foundation for the environmental monitoring of reservoirs", October 26-29, 2010. Khabarovsk: Institute for Water and Environmental Problems of the Far East Branch of the Russian Academy of Sciences, pp. 53-56.

7. Zhindarev, L. A. (ed.). (2009). Man-made lake shore management. Novosibirsk: Siberian Branch of the Russian Academy of Sciences, $239 \mathrm{p}$.

8. Matarzin, Yu. M. (2003). Hydrology of reservoirs: study guide for universities. Perm: Publishing House of the Perm State University, $295 \mathrm{p}$.

9. Popov, P. A. and Viser, A.M. (2011). Influence of the water level of the Novosibirsk reservoir on reproductive potential of fishes. The World of Science, Culture and Education, No. 1 (26). pp. 353-356.

10. Savkin, V. M. (2000). Environmental and geographical changes in the river basins of Western Siberia (in the case of large-scale water management activities). Novosibirsk: Nauka, $152 \mathrm{p}$.

11. Savkin, V. M. (2006). Current hydrological regime at the Novosibirsk reservoir in comparison with the long-term one. Hydrology and hydroecology of the Western Ural. Perm: Perm University, pp. 5-12.
12. Savkin, V. M. (2015). Influence of Novosibirsk reservoir on the transformation of high and low water level extreme hydrological events. In: Proceedings of the International Scientific and Practical Conference "Current issues of reservoirs and their catchment areas", Vol. 1. Hydro-and geodynamic processes of water management. Perm: Perm State National Research University, pp. 128-132.

13. Savkin, V. M. and Dvurechenskaya, S. Ya. (2017). Transformation of water flow of Upper $\mathrm{Ob}$ due to man impact. In: Proceedings of the $6^{\text {th }}$ International Scientific and Practical Conference "Current issues of reservoirs and their catchment areas", Vol. 1. Hydro-and geodynamic processes. Water resources management. Perm: Perm State National Research University, pp. 227-231.

14. Savkin, V. M. and Dvurechenskaya, S. Ya. (2017). Formation and utilization of water resources of Upper Ob river (Novosibirsk reservoir) under natural and technogenic conditions. In: Proceedings of the $3^{\text {rd }}$ All-Russian Scientific Conference with International Participation "Water and environmental problems of Siberia and Central Asia", Vol. III. Barnaul: Institute for Water and Environmental Problems of the Siberian Branch of the Russian Academy of Sciences, pp. 266-277.

15. Repository for legal documents, standards, regulations and specifications (2011). Recommendations R 52.24.3092011. Organizing and conducting monitoring observations over surface water pollution in the Rosgidromet network. [online] Available at: http://docs.cntd.ru/document/1200049047 [Date accessed 17.02.2020].

16. Calijuri, M. L., Castro, J. d. S., Costa, L. S., Assemany, P. P. and Alves, J. E. M. (2015). Impact of land use/land cover changes on water quality and hydrological behavior of an agricultural subwatershed, Environmental Earth Sciences, Vol. 74, Issue 6, pp. 5373-5382. DOI: 0.1007/s12665-0154550-0.

17. Interesova, E. A., Yadrenkina, E. N. and Savkin, V. M. (2009). Spatial organization of the spawning grounds of cyprinidae and the regulated flow of the Upper Ob. Journal of Ichthyology, Vol. 49, Issue 1, pp. 73-79.

18. Savkin, V. M. and Dvurechenskaya, S. Ya. (2014). Resources-related and water-environmental problems of the integrated use of the Novosibirsk Reservoir. Water Resources, Vol. 41, Issue 4, pp. 446-453.

19. Setegn, S. G. (2015). Water resources management for sustainable environmental public health. In: Setegn, S. G., Donoso, M. C. (eds.) Sustainability of integrated water resources management: water governance, climate and ecohydrology. Cham: Springer, pp. 275-287. DOI: 10.1007/978-3-319-121949_15.

20. Vasil'ev, O. F., Savkin, V. M., Dvurechenskaya, S. Ya. and Popov, P. A. (1997). Water-management and environmental problems of the Novosibirskoe Reservoir. Water Resources, Vol. 24, No. 5, pp. 538-545. 


\section{Авторы}

Савкин Валерий Михайлович, д-р географ. наук

Институт водных и экологических проблем Сибирского отделения РАН, г. Барнаул, Россия

Двуреченская Серафима Яковлевна, канд. хим. наук, доцент

Институт водных и экологических проблем Сибирского отделения РАН, г. Барнаул, Россия

E-mail: dvur@iwep.nsc.ru, serafima_dv@mail.ru

\section{Кондакова Ольга Владимировна}

Институт водных и экологических проблем Сибирского отделения РАН, г. Барнаул, Россия

E-mail: kondakova@iwep.nsc.ru

\section{Authors}

Savkin Valery Mikhailovich, Dr. of Geography

Institute for Water and Environmental Problems, Siberian Branch of the Russian Academy of Sciences, Barnaul, Russia

Dvurechenskaya Serafima Yakovlevna, PhD. in Chemistry, Associate Professor

Institute for Water and Environmental Problems, Siberian Branch of the Russian Academy of Sciences, Barnaul, Russia

E-mail: dvur@iwep.nsc.ru,serafima_dv@mail.ru

\section{Kondakova Olga Vladimirovna}

Institute for Water and Environmental Problems, Siberian Branch of the Russian Academy of Sciences, Barnaul, Russia

E-mail:kondakova@iwep.nsc.ru 